Rev. Fac. Agron. (LUZ). 2021, 38(4): 951-969. Octubre-Diciembre.

\title{
Characterization of rhizospheric bacteria isolated from soil cultivated with sugarcane in Tamaulipas state, Mexico
}

Caracterización de bacterias rizosféricas aisladas de suelo cultivado con caña de azúcar en el estado de Tamaulipas, México

Caracterização de bactérias rizosféricas isoladas de solo cultivado com cana-de-açúcar no estado de Tamaulipas, México

Jesús Gerardo García Olivares ${ }^{1}$, Martín Abraham Reyes Lara $^{2}$, Juan flores Gracía ${ }^{2}$ Jesús Di Carlo Quiroz Velásquez Israel García León ${ }^{1}$, José Reyes Hernández ${ }^{3}$ y Homar Rene Gill Langarica ${ }^{1^{*}}$

${ }^{1}$ Centro de Biotecnología Genómica-Instituto Politécnico Nacional, Reynosa, Tamaulipas, México C.P. 88710. Correo electrónico: (JG) jggarcia@ipn.mx, (D; (JQ) jquiroz@ipn. mx, (D); (IG) ${ }^{1 e}$ igleon00@gmail.com, (D); (HG) hgill@ipn.mx, (iD. ${ }^{2}$ Instituto Tecnológico de Cd. VictoriaCd. Victoria, Tamaulipas, México C.P. 87010. Correo electrónico: (MR) tinorey_90@hotmail.com, (D); (JG) jfloresgracia@yahoo.com.mx, (D. ${ }^{3}$ Universidad Autónoma de Tamaulipas Unidad Académica Multidisciplinaria Mante, Col. Jardín C.P. 89840, México. Correo electrónico: biologo.reyes@hotmail.com, (D.

\section{Abstract}

The state of Tamaulipas, Mexico, has two important sugar mills, with plantations of sugarcane (Saccharum officinarum L.) of more than 50 years, the objective of the study was the identification and bacterial characterization in the production of indole-3-acetic acid (IAA), the solubilization of phosphorus and plant growth of bacterial isolates from the rhizosphere of sugarcane. The isolation and morphological characterization were in 30 rhizosphere soil samples of the sugarcane variety CP 72-2086 using the Luria-Bertani media, Congo Red Agar and Potato Dextrose Agar. The molecular characterization was with the 16S rRNA gene

Received el 14-02-2021 • Accepted el 28-05-2021.

*Autor de correspondencia. Correo electrónico: hgill@ipn.mx; jggarcia@ipn.mx 


\section{Rev. Fac. Agron. (LUZ). 2021, 38(4): 951-969. Octubre-Diciembre.}

García et al.

ISSN 2477-9407

and the bacterial inoculation consisted of seedlings of the variety CP 72-2086. 121 strains (38 species) were isolated, being Bacillus sp. most frequently, 14 species were positive for phosphorus solubilization: Bacillus sp. (6), Pseudomonas spp. (5), Paenibacillus (2) Streptomyces venezuelae (1) stand out. The greater phosphorus solubilization was Pseudomonas mediterranea $(21.6 \mathrm{~mm})$. Nine bacteria showed production close to $5 \mathrm{ppm}$ IAA: Bacillus aryabhattai $(6 \mathrm{ppm})$, Bacillus pumilus (5.8 ppm) and Ensifer adhaerens (5.6 ppm). Bacillus megaterium showed a higher percentage of chlorophyll and foliar nitrogen. In the present analysis, 38 bacterial species associated with the rhizosphere of the sugarcane variety CP 72-2086 were identified, so these results showed the potential to select native bacteria that have the ability to stimulate plant growth of the variety CP 72-2086.

Key words: Saccharum officinarum L., Bacillus spp., indole-3-acetic acid (IAA), phosphorus.

\section{Resumen}

El estado de Tamaulipas, México, cuenta con dos ingenios azucareros importantes, con plantaciones de caña de azúcar (Saccharum officinarum L.) de más de 50 años, el objetivo del estudio fue la identificación y la caracterización bacteriana en la producción de ácido indol-3-acético (IAA), la solubilización de fósforo y crecimiento vegetal de aislados bacterianos de la rizosfera de caña de azúcar. El aislamiento y la caracterización morfológica fue en 30 muestras de suelo de la rizosfera de la variedad de caña de azúcar CP 72-2086 usando los medios Luria-Bertani, agar rojo congo y agar papa dextrosa. La caracterización molecular fue con el gen 16S rRNA y la inoculación bacteriana consistió en plántulas de la variedad CP 72-2086. Se aislaron 121 cepas, Bacillus sp. fue la bacteria más frecuente, 14 especies fueron positivos a fósforo, Bacillus sp. (6), Pseudomonas spp. (5), Paenibacillus (2) Streptomyces venezuelae (1). La mayor solubilización de fósforo fue para Pseudomonas mediterranea $(21,6 \mathrm{~mm})$. Nueve bacterias presentaron una producción cercana a $5 \mathrm{ppm}$ de IAA, sobresalen Bacillus aryabhattai (6 ppm), Bacillus pumilus (5,8 ppm) y Ensifer adhaerens (5,6 ppm). Bacillus megaterium mostró mayor porcentaje de clorofila y nitrógeno foliar. En el presente análisis se lograron identificar 38 especies bacterianas asociadas a la rizosfera de la variedad de caña de azúcar CP 72-2086, por lo que estos resultados mostraron el potencial para seleccionar bacterias nativas que tienen la capacidad de estimular el crecimiento vegetal de la variedad CP 72-2086.

Palabras clave: Saccharum officinarum L., Bacillus spp., ácido indol-3-acético (IAA), fósforo.

\section{Resumo}

O estado de Tamaulipas, no México, possui duas importantes usinas açucareiras, com plantações de cana-de-açúcar (Saccharum officinarum L.) de mais de 50 anos, 


\section{Rev. Fac. Agron. (LUZ). 2021, 38(4): 951-969. Octubre-Diciembre.}

\section{García et al.}

o objetivo do estudo foi a identificação e caracterização bacteriana na produção de ácido indol- 3- ácido acético (IAA), solubilização de fósforo e crescimento de plantas de isolados bacterianos da rizosfera da cana-de-açúcar. O isolamento e a caracterização morfológica foram realizados em 30 amostras de solo da rizosfera da variedade de cana-de-açúcar CP 72-2086 utilizando os meios Luria-Bertani, ágar vermelho do Congo e ágar batata dextrose. A caracterização molecular foi com o gene $16 \mathrm{~S}$ rRNA e a inoculação bacteriana consistiu em mudas da variedade $\mathrm{CP}$ 72-2086. 121 cepas, Bacillus sp. foi a bactéria mais frequente, 14 espécies foram positivas para fósforo, Bacillus sp. (6), Pseudomonas spp. (5), Paenibacillus (2) Streptomyces venezuelae (1). A maior solubilização de fósforo foi para Pseudomonas mediterranea $(21,6 \mathrm{~mm})$. Nove bactérias apresentaram produção próxima a $5 \mathrm{ppm}$ de IAA, destacando-se Bacillus aryabhattai (6 ppm), Bacillus pumilus (5,8 ppm) e Ensifer adhaerens (5,6 ppm). Bacillus megaterium apresentou maior porcentagem de clorofila e nitrogênio foliar. Na presente análise, foram identificadas 38 espécies bacterianas associadas à rizosfera da variedade de cana-de-açúcar CP 72-2086, portanto esses resultados mostraram o potencial para selecionar bactérias nativas que têm a capacidade de estimular o crescimento de plantas da variedade CP 72 2086.

Palabras-chave: Saccharum officinarum L., Bacillus spp., ácido indol-3-acético (IAA), fósforo.

\section{Introduction}

The sugarcane (Saccharum officinarum L.) cultivation in Mexico is one activity of major importance in the national economy, it is a crop that allows a wide production diversity, an example in Tamaulipas sugar mills "Aarón Sáenz Garza" and "El Mante" generate a great economic spill (Castro-Nava et al., 2010). The activity derived from sugarcane cultivation in Mexico producing areas is not only affected productively and economically by biotic and abiotic factors also is cultivated under the monoculture system, a practice that has impoverished and degraded soil (Solanki et al., 2017). Conditions that have been aggravated by practices applying high agrochemicals amounts and chemical fertilizers (Torriente,

\section{Introducción}

El cultivo de la caña de azúcar (Saccharum officinarum L.) en México es una actividad de gran importancia en la economía nacional, es un cultivo que permite una amplia diversidad productiva, ejemplo en Tamaulipas los ingenios azucareros "Aarón Sáenz Garza" y "El Mante" generan un gran derrame económico (Castro-Nava et al., 2010). La actividad derivada del cultivo de la caña de azúcar en las zonas productoras de México no solo se ve afectada productiva y económicamente por factores bióticos y abióticos también se cultiva bajo el sistema de monocultivo, práctica que ha empobrecido y degradado los suelos (Solanki et al., 2017). Estas condiciones se han visto agravadas por prácticas que aplican altas cantidades de 


\section{Rev. Fac. Agron. (LUZ). 2021, 38(4): 951-969. Octubre-Diciembre.}

2010). Therefore, it is necessary to investigate cultivation technologies are profitable and do not affect environment with more sustainable cultivation practices.

One way to temper bad practices is through soil microflora study, coupled with implementation agricultural practices that stimulate native populations of microorganisms in sugarcane rhizosphere cultivation, growth and health of plants (Momose et al., 2009; Ashraf et al., 2011; Saharan and Nehra, 2011), since we must take advantage of fact soil microorganisms are associated with crops, based on those interact positively with plants (Morgan et al., 2005; Bhattacharyya and Jha, 2012; Quecine et al., 2012), and also from adaptive point view, plants select microorganisms that contribute most its development, for example, bacteria of genus Pseudomonas, Azospirillum, Azotobacter, Klebsiella, Enterobacter, Alcaligens, Arthrobacter, Burkholderia, Bacillus and Serratia, among others can colonize plant tissue (Saharan and Nehra, 2011; Criollo et al., 2012), as well as fungi that have been proven to promote plant growth such as those of genus Trichoderma, which has been reported that stimulate growth grasses such as sorghum and maize among others plants (Hernández-Mendoza et al., 2018).

Investigations show potential to select in situ microorganisms with potential to optimize assimilate nutrients and possess substances stimulate plant growth or act as bioinsecticides or biofungicides, agroquímicos y fertilizantes químicos (Torriente, 2010). Por lo tanto, es necesario investigar las tecnologías de cultivo que sean rentables y no afecten el medio ambiente con prácticas de cultivo más sostenibles.

Una forma de moderar las malas prácticas es mediante el estudio de la microflora del suelo, junto con la implementación de prácticas agrícolas que estimulen las poblaciones nativas de microorganismos en el cultivo, el crecimiento y la salud de las plantas en la rizosfera de la caña de azúcar (Momose et al., 2009; Ashraf et al., 2011; Saharan y Nehra, 2011), ya que debemos aprovechar el hecho de que los microorganismos del suelo están asociados con los cultivos, en base a que estos interactúan positivamente con las plantas (Morgan et al., 2005; Bhattacharyya y Jha, 2012; Quecine et al., 2012), y también desde el punto de vista adaptativo, las plantas seleccionan los microorganismos que más contribuyen a su desarrollo, por ejemplo, bacterias de los géneros Pseudomonas, Azospirillum, Azotobacter, Klebsiella, Enterobacter, Alcaligens, Arthrobacter, Burkholderia, Bacillus y Serratia, entre otros pueden colonizar tejido vegetal (Saharan y Nehra, 2011; Criollo et al., 2012), así como hongos que han demostrado promover el crecimiento de las plantas como los del género Trichoderma, que se ha reportado que estimulan el crecimiento de gramíneas como sorgo y maíz entre otras plantas (HernándezMendoza et al., 2018).

Las investigaciones muestran potencial para seleccionar microorganismos in situ con potencial 


\section{Rev. Fac. Agron. (LUZ). 2021, 38(4): 951-969. Octubre-Diciembre.}

García et al.

ISSN 2477-9407

because they are native microbiota and have a high degree adaptation. Therefore, to know the bacterial diversity associated with the cultivation of sugarcane and its potential as biofertilizers, is a first step to take advantage of the benefits that lead to the association of the sugarcane plant and rhizobacteria in the productive system of sugar mills "Aarón Sáenz Garza" and "El Mante" in Tamaulipas Mexico, for these reasons, the main objective of the study was to evaluate the production of indole-3-acetic acid, the solubilization of mineral phosphorus and the production of shoots in the greenhouse from bacteria isolated from the rhizosphere of sugarcane cultivated in calcareous soils from the state of Tamaulipas, Mexico.

\section{Materials and methods}

Location. For this study, soils of sugarcane mills in the municipalities El Mante (latitude N 22 74'78.30" and length E 98 98'27.99"), Gómez Farías (latitude N 22\%42'32" and length E $\left.0^{\circ} 30^{\prime} 43^{\prime \prime}\right)$ and Xicoténcatl (latitude N 22 $59^{\circ} 00^{\prime \prime}$ and length E 98 $\left.57^{\circ} 00^{\prime \prime}\right)$ from Tamaulipas state, Mexico, were selected. The microbiology study was carried out in soil grow with sugarcane variety CP 72-2086.

Soil samples collection and samples preparation. In 30 randomly chosen plots, five soil samples were collected from the rhizosphere of the sugarcane plant. Samples were collected at a depth $30 \mathrm{~cm}$ composed of five points in each lot and subsequently homogenized and dried para optimizar la asimilación de nutrientes y poseer sustancias que estimulen el crecimiento de las plantas o actúen como bioinsecticidas o biofungicidas, debido a que son microbiota nativa y tienen un alto grado de adaptación. Por tanto, conocer la diversidad bacteriana asociada al cultivo de la caña de azúcar y su potencial como biofertilizantes, es el primer paso para aprovechar los beneficios que conllevan la asociación de la planta de caña de azúcar y rizobacterias en el sistema productivo de los ingenios azucareros “Aarón Sáenz Garza “y” El Mante “en Tamaulipas México, por estas razones, el objetivo principal del estudio fue evaluar la producción de ácido indol3-acético, la solubilización de fósforo mineral y la producción de brotes en invernadero a partir de bacterias aisladas de la rizosfera de caña de azúcar cultivada en suelos calcáreos del estado de Tamaulipas, México.

\section{Materiales y métodos}

Localización. Para este estudio, fueron seleccionados suelos de ingenios de caña de azúcar en los municipios El Mante (latitud N 22 $74^{\prime} 78.30$ " y longitud E 9898'27.99"), Gómez Farías (latitud N 22 $42^{\circ} 32^{\prime \prime}$ y longitud E $0^{\circ} 30$ '43") y Xicoténcatl (latitud N $22^{\circ} 59^{\prime} 00^{\prime \prime}$ y longitud E $\left.98^{\circ} 57^{\prime} 00^{\prime \prime}\right)$ del estado de Tamaulipas, México. El estudio de microbiología se realizó en suelo de cultivo con caña de azúcar variedad CP 72-2086.

Toma de muestras de suelo y preparación de muestras. En 30 parcelas elegidas al azar, se 


\section{Rev. Fac. Agron. (LUZ). 2021, 38(4): 951-969. Octubre-Diciembre.}

in shade. Bacterial isolation consisted of using $1 \mathrm{~g}$ of soil diluted in sterile isotonic saline, $100 \mu \mathrm{L}$ of the dilution in triplicate was placed in sterile Petri dishes with growth medium and incubated at $30{ }^{\circ} \mathrm{C}$ for 48 hours. The selection of the colonies was carried out by morphology and the counting of the colonies was done by the method of Swanson et al. (2001), three culture media, Luria-Bertani (LB), congo red agar and potato dextrose agar (PDA) were used for bacterial isolation (Berkhoff and Vinal, 1986).

Molecular identification. The protocol PrepMan ${ }^{\circledR}$ Ultra Sample Preparation Reagent of Applied Biosystems for DNA was used (Mullis and Faloona, 1987), the protocol allowed to perform a PCR directly. The $16 \mathrm{~S}$ rRNA gene was amplified using universal primer Sx(AGAGTTTGATCMTGGCTCAG) and Ay-(ACCTTGTTACGACTT) (Naveed et al., 2014). Amplification cycle was included an initial denaturation (94 ${ }^{\circ} \mathrm{C}, 5 \mathrm{~min}$ ), 30 cycles consisted of $1 \mathrm{~min}$ at $94{ }^{\circ} \mathrm{C}$ for denaturation, $40 \mathrm{~s}$ at 58 ${ }^{\circ} \mathrm{C}$ for annealing and $150 \mathrm{~s}$ at $72^{\circ} \mathrm{C}$ for elongation, followed $10 \mathrm{~min}$ at $72{ }^{\circ} \mathrm{C}$ final extension. Target amplification was confirmed by electrophoresis in $1 \%$ agarose. The PCR products were sequenced and compared with $16 \mathrm{~S}$ rRNA gene sequences present in the NCBI GenBank.

Based on a literature review, a percentage of the bacterial isolates were selected to produce IAA, mineral phosphorus solubilization, and greenhouse plant inoculation tests. For phosphorus solubilization, Pikovskaya agar medium (PVK) with recolectaron cinco muestras de suelo de la rizósfera de la planta de caña de azúcar. Las muestras se recolectaron a una profundidad de $30 \mathrm{~cm}$, estuvo compuesta por cinco puntos en cada lote, posteriormente se homogeneizaron y secaron a la sombra. El aislamiento bacteriano consistió en utilizar $1 \mathrm{~g}$ de suelo diluido en solución salina isotónica estéril, se colocaron $100 \mu \mathrm{L}$ de la dilución por triplicado en placas de Petri estériles con medio de cultivo y se incubaron a $30{ }^{\circ} \mathrm{C}$ durante 48 horas. La selección de las colonias se realizó por morfología y el recuento de las colonias se realizó por el método de Swanson et al. (2001), se utilizaron tres medios de cultivo, Luria-Bertani (LB), agar rojo congo y agar papa dextrosa (PDA) para el aislamiento bacteriano (Berkhoff y Vinal, 1986).

Identificación molecular. Se utilizó el protocolo PrepMan ${ }^{\circledR}$ Ultra Sample Preparation Reagent de Applied Biosystems para ADN (Mullis y Faloona, 1987), el protocolo permitió realizar una PCR directamente. El gen de $\mathrm{ARNr}$ 16S se amplificó utilizando el cebador universal Sx(AGAGTTTGATCMTGGCTCAG) y Ay- (ACCTTGTTACGACTT) (Naveed et al., 2014). El ciclo de amplificación incluyó una desnaturalización inicial $\left(94{ }^{\circ} \mathrm{C}, \quad 5 \mathrm{~min}\right), \quad 30$ ciclos consistieron en 1 min a $94{ }^{\circ} \mathrm{C}$ para la desnaturalización, $40 \mathrm{~s}$ a 58 ${ }^{\circ} \mathrm{C}$ para el recocido y $150 \mathrm{~s}$ a $72{ }^{\circ} \mathrm{C}$ para el alargamiento, seguidos de 10 min a Extensión final $72{ }^{\circ} \mathrm{C}$. La amplificación diana se confirmó mediante electroforesis en agarosa al $1 \%$. Los productos de la PCR se secuenciaron y compararon con las 


\section{Rev. Fac. Agron. (LUZ). 2021, 38(4): 951-969. Octubre-Diciembre.}

purple bromocresol solution was used as culture $\mathrm{pH}$ indicator (changes from violet to yellow), which indicates the medium acidification. $10 \mu \mathrm{L}$ of each strain were cultured in PVK medium plates and incubated for 7 days at 30 ${ }^{\circ} \mathrm{C}$. The appearance of a clear zone around the colony was considered as its phosphate solubility capacity. The phosphorus solubility index (SI) was calculated from relationship between the diameter of colony and halo zone (Nopparat et al., 2009).

Biochemical characterization. In IAA analysis, the strains were grown in LB liquid medium for 24 and $48 \mathrm{~h}$ and filtered with $0.45 \mu \mathrm{m}$ nylon membranes (Millipore), each sample was composed of $3 \mathrm{~mL}$ deionized water and $3 \mathrm{~mL}$ of a suspension $1.10^{6}$ cells. $\mathrm{mL}^{-1}$. HPLC analysis was performed by injecting $20 \mu \mathrm{L}$ of each filtered sample and as a standard IAA solution. All sample analysis was transformed in mobile phase 70/30 (700 $\mathrm{mL}$ of phosphate solution and $300 \mathrm{~mL}$ of acetonitrile) with $\mathrm{pH} 3.2$, a flow rate $1 \mathrm{~mL} \mathrm{~min}^{-1}$ for $25 \mathrm{~min}$ at $30{ }^{\circ} \mathrm{C}$, UV light detector at $220 \mathrm{~nm}$ and column ultra-pore of $150 * 4.6 \mathrm{~mm}$ (Arora and Bae, 2014).

Greenhouse test. The effect as bio stimulators of plant growth of nine isolated bacteria selected for their production of IAA a phosphorus solubilization was evaluated in a greenhouse in 20 seedlings sugarcane variety $\quad \mathrm{CP} \quad 72-2086 \quad$ (Bacillus aryabhattai, $B$. licheniformis, $B$. megaterium, B. pumilus, B. simplex, $B$ subtilis, Brevundimonas aurantiaca, Ensifer adhaerens, Pseudomonas sp. and control). The analysis was secuencias del gen del ARNr 16S presentes en el NCBI GenBank.

En base a una revisión de la literatura, se seleccionó un porcentaje de los aislados bacterianos para producir IAA, solubilización de fósforo mineral e inoculación de plantas de invernadero. Para la solubilización del fósforo se utilizó medio de agar Pikovskaya (PVK) con solución de bromocresol púrpura como indicador del $\mathrm{pH}$ del cultivo (cambios de violeta a amarillo), lo que indica la acidificación del medio. Se cultivaron 10 $\mu \mathrm{l}$ de cada cepa en placas de medio PVK y se incubaron durante 7 días a $30{ }^{\circ} \mathrm{C}$. La aparición de una zona clara alrededor de la colonia se consideró como su capacidad de solubilidad de fosfato. El índice de solubilidad del fósforo (SI) se calculó a partir de la relación entre el diámetro de la colonia y la zona del halo (Nopparat et al., 2009).

\section{Caracterización bioquímica.} En el análisis IAA, las cepas se cultivaron en medio líquido LB durante 24 y $48 \mathrm{~h}$ y se filtraron con membranas de nylon de 0,45 $\mu \mathrm{m}$ (Millipore), cada muestra estuvo compuesta por $3 \mathrm{~mL}$ de agua desionizada $\mathrm{y}$ $3 \mathrm{~mL}$ de una suspensión de $1.10^{6}$ células.mL ${ }^{-1}$. El análisis por HPLC se realizó inyectando $20 \mu \mathrm{L}$ de cada muestra filtrada y como una solución estándar de IAA. Todo el análisis de la muestra se transformó en fase móvil 70/30 (700 mL de solución de fosfato y $300 \mathrm{~mL}$ de acetonitrilo) con $\mathrm{pH} 3,2$, un caudal de $1 \mathrm{~mL} \mathrm{~min}^{-1}$ durante $25 \mathrm{~min}$ a $30{ }^{\circ} \mathrm{C}$, detector de luz UV a $220 \mathrm{~nm}$ y columna ultra-pore de $150 * 4,6 \mathrm{~mm}$ (Arora y Bae, 2014).

Prueba de invernadero. Se evaluó el efecto como bioestimuladores 


\section{Rev. Fac. Agron. (LUZ). 2021, 38(4): 951-969. Octubre-Diciembre.}

carried in El Mante municipality in Tamaulipas state, Mexico (latitude $\mathrm{N} 22^{\circ} 74$ '78.30" and length E $98^{\circ} 98^{\prime}$ 27.99"). Each sugarcane seedling of cultivar CP 72-2086 was transplanted in bags with substrate composted cachaça (six kilograms) $10 \mathrm{~cm}$ to depth. One milliliter each strain bacterial was applied to root. The Chlorophyll and nitrogen content and shoots number were evaluated.

Statistical

analysis

and experimental design. For the bacterial evaluation in production phosphorus solubilization and greenhouse test, a completely randomized block experimental design was used with three repetitions for phosphorus solubilization and 20 repetitions (plants) for the greenhouse test. For the two evaluations an ANOVA and Tukey's means test were applicate $(\mathrm{P}=0.05)$ in the software InfoStat v2019 (Di Rienzo et al., 2019). For the phylogenetic tree was constructed with the Kimura 2-parameters method (Kimura, 1980) and the maximum probability with a resampling of 10,000 repetitions (Felsenstein, 1985) and the MEGA V6.0 software was used.

\section{Results and discussion}

Bacterial diversity. Morphology isolation allowed identification of 121 pure isolates from sugarcane rhizosphere, identification based on 16S rRNA gene allowed identification of 38 species grouped in nine genera and three phyla, Actinobacteria, Proteobacteria and Firmicutes. Of total species identified, the del crecimiento vegetal de nueve bacterias aisladas seleccionadas para su producción de IAA a solubilización de fósforo en invernadero en 20 plántulas de caña de azúcar variedad CP 72-2086 (Bacillus aryabhattai, B. licheniformis, B. megaterium, B. pumilus, B. simplex, B subtilis, Brevundimonas aurantiaca, Ensifer adhaerens, Pseudomonas sp. y control). El análisis se realizó en el municipio El Mante en el estado de Tamaulipas, México (latitud N 22 $74^{\circ} 78,30^{\prime \prime}$ y longitud E $98^{\circ} 98$ '27,99'). Cada plántula de caña de azúcar del cultivar CP 72-2086 se transplantó en bolsas con sustrato compostado de cachaza (seis kilogramos) a $10 \mathrm{~cm}$ de profundidad. Se aplicó a la raíz un mililitro de cada cepa bacteriana. Se evaluó el contenido de clorofila y nitrógeno y el número de brotes.

Análisis estadístico y diseño experimental. Para la evaluación bacteriana en producción de solubilización de fósforo y prueba de invernadero, se utilizó un diseño experimental de bloques completamente al azar con tres repeticiones para la solubilización de fósforo y 20 repeticiones (plantas) para la prueba de invernadero. Para las dos evaluaciones se aplicaron ANAVAR y prueba de medias de Tukey $(\mathrm{P}=$ 0,05) en el software InfoStat v2019 (Di Rienzo et al., 2019). Para el árbol filogenético se construyó con el método de 2 parámetros de Kimura (Kimura, 1980) y máxima probabilidad con un remuestreo de 10.000 repeticiones (Felsenstein, 1985) y el software MEGA V6.0. 
Rev. Fac. Agron. (LUZ). 2021, 38(4): 951-969. Octubre-Diciembre.

García et al.

genera Bacillus, Pseudomonas and Arthrobacter grouped largest number of species. At phylum level, the phylum Firmicutes grouped largest number of species (26), Proteobacteria eight and Actinobacteria four species (figure 1).
Resultados y discusión

Diversidad bacteriana. El aislamiento morfológico permitió identificar 121 aislados puros de la rizósfera de la caña de azúcar, la

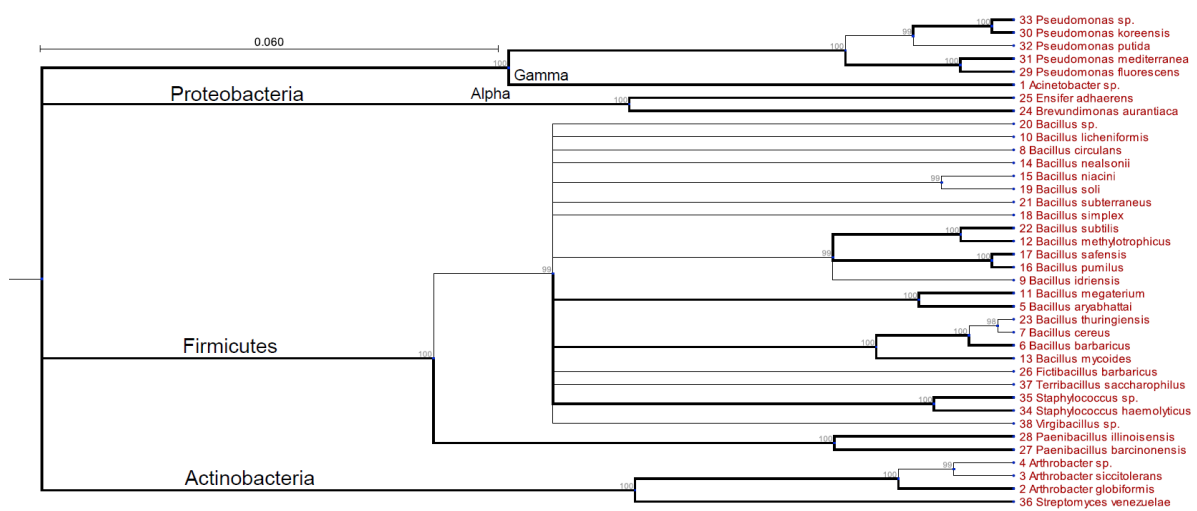

Figure 1. Phylogenetic relationship of 16S rRNA gene in bacteria isolated from sugarcane rhizosphere grown in southern Tamaulipas state, Mexico.

Figura 1. Relación filogenética del gen 16S rRNA en bacterias aisladas de la rizosfera de caña de azúcar cultivada en el sur del estado de Tamaulipas, México.

The results in bacterial diversity found in this work coincide with that reported by Dhanraj (2013), who found a similar number of phyla and bacterial genera in the rhizosphere of sugarcane and that reported by Cordero et al. (2020) in the rhizosphere of the other crops as canola, wheat, field pea and lentil. In this work, 38 species located in three phyla were identified, Actinobacteria, Proteobacteria and Firmicutes, $50 \%$ of the bacteria belonged to the genus Bacillus within the phylum Firmicutes. Pisa et al. (2011), found in their investigation identificación basada en el gen $16 \mathrm{~S}$ rRNA permitió identificar 38 especies agrupadas en nueve géneros $\mathrm{y}$ tres filos, Actinobacteria, Proteobacteria y Firmicutes. Del total de especies identificadas, los géneros Bacillus, Pseudomonas y Arthrobacter agruparon el mayor número de especies. A nivel de filo, el filo Firmicutes agrupó el mayor número de especies (26), Proteobacteria ocho y Actinobacteria cuatro especies (figura 1).

Los resultados en diversidad bacteriana encontrados en este trabajo coinciden con lo reportado por Dhanraj 


\section{Rev. Fac. Agron. (LUZ). 2021, 38(4): 951-969. Octubre-Diciembre.}

García et al.

ISSN 2477-9407

of sugarcane rhizosphere that genus Bacillus is present in $19.7 \%$ more than other genera found and as well as Männistö et al. (2013), who reported that Bacillus genus had a greater presence in soils cultivated with crops of commercial interest (Cordero et al., 2020).

The wide presence of genus Bacillus in soils cultivated with sugarcane, may be related to fact that genus Bacillus species could produce spores, which allows each species to tolerate unfavorable environmental conditions compared to other genera (Galperin, 2013). Furthermore, it is known that Bacillus strains are producers lipopeptide biosurfactants of surfactin, iturin and fengycin families that demonstrate biological activity with a synergistic mode of action (Heryania and Dharma Putrab, 2017).

In addition, surfactin shows antibacterial, antiviral, antiparasitic properties and triggers formation of biofilms, which are essential for root colonization, Iturin and fengycin exhibit antifungal activity against a wide range of yeast and filamentous fungi, together stimulate an induced systemic response (ISR) in host plants, for what are considered microorganisms with industrial and agricultural potential (Lim et al., 2017).

Phosphorus solubilization. Of 38 species of detected bacteria, only one isolate per species was analyzed for phosphorus solubilization, the result showed that less than $50 \%$ of the strains can solubilize insoluble phosphorus, the same result was
(2013), quien encontró un número similar de phyla y géneros bacterianos en la rizosfera de la caña de azúcar y al reportado por Cordero et al. (2020) en la rizósfera de los otros cultivos como canola, trigo, guisante y lentejas. En este trabajo se identificaron 38 especies ubicadas en tres phyla, Actinobacteria, Proteobacteria y Firmicutes, el $50 \%$ de las bacterias pertenecían al género Bacillus dentro del Phylum Firmicutes. Pisa et al. (2011), encontraron en su investigación de la rizósfera de la caña de azúcar que el género Bacillus está presente en un 19,7 \% más que otros géneros encontrados y al igual que Männistö et al. (2013), quienes reportaron que el género Bacillus tuvo una mayor presencia en suelos cultivados con cultivos de interés comercial (Cordero et al., 2020).

La amplia presencia del género Bacillus en suelos cultivados con caña de azúcar, puede estar relacionada con el hecho de que las especies del género Bacillus podrían producir esporas, lo que permite que cada especie tolere condiciones ambientales desfavorables en comparación con otros géneros (Galperin, 2013). Además, se sabe que las cepas de Bacillus son productoras de biosurfactantes lipopéptidos de las familias de surfactina, iturina y fengycina que demuestran actividad biológica con un modo de acción sinérgico (Heryania y Dharma Putrab, 2017).

Además, la surfactina muestra propiedades antibacterianas, antivirales, antiparasitarias y desencadena la formación de biopelículas, que son esenciales para 
Rev. Fac. Agron. (LUZ). 2021, 38(4): 951-969. Octubre-Diciembre.

García et al.

ISSN 2477-9407

reported by Mohammadi (2012), la colonización de raíces, Iturin y who observed a lower efficacy than $50 \%$ in solubilization insoluble phosphorus. The variance analysis was highly significant for phosphorus solubilization time (24, 48 and $72 \mathrm{~h}$ ) and treatments (bacterial) (table 1).

Tukey's test $(\mathrm{P}=0.05)$ showed that Pseudomonas mediterranea $(21.6 \mathrm{~mm})$ had highest phosphorus solubilization, followed by Bacillus aryabhattai (14.4 $\mathrm{mm}$ ) (table 2). fengycin exhiben actividad antifúngica contra una amplia gama de levaduras y hongos filamentosos, juntos estimulan una respuesta sistémica inducida (ISR) en plantas hospedantes, por lo que se consideran microorganismos con potencial industrial y agrícola (Lim et al., 2017).

Solubilización de fósforo. De 38 especies de bacterias detectadas, solo se analizó un aislado por

Table 1. Analysis of variance of phosphorus solubilization test in bacteria isolated from sugarcane rhizosphere in Tamaulipas state, Mexico.

Cuadro 1. Análisis de varianza de la prueba de solubilización de fósforo en bacterias aisladas de la rizósfera de la caña de azúcar en el estado de Tamaulipas, México.

\begin{tabular}{cccccc}
\hline Variationsource & Freedom degrees & Squares sum & Middle squares & f calc. & prob. \\
\hline Treatments & 125 & 134.75 & 8.93 & 5.84 & $0.0001^{* *}$ \\
Repetitions & 3 & 2.71 & 0.90 & 0.59 & $0.624 \mathrm{~ns}$ \\
Time & 1 & 1915.15 & 1915.15 & 1244.6 & $0.001^{* *}$ \\
Treat*Rep & 45 & 668.38 & 14.85 & 9.65 & $0.001^{* *}$ \\
Time*Rep & 15 & 1235.84 & 82.38 & 53.55 & $0.001^{* *}$ \\
Error & 112 & 172.33 & 1.53 & & \\
CV & $12 \%$ & & & & \\
\hline
\end{tabular}

$\mathrm{CV}=$ Coefficient of variation, $\mathrm{ns}=$ no significance $(\mathrm{P}=0.01)$.

$\mathrm{CV}=$ Coeficiente de variación, $\mathrm{ns}=\sin$ significancia $(\mathrm{P}=0,01)$.

This is important since phosphorus is one of the essential macroelements necessary for plant growth and development, however, there is only a small fraction of phosphorus in the soil solution (1 ppm or $0.1 \%$ ) (Awais et al., 2017). The phosphate-solubilizing bacteria (PSB) have ability to solubilize insoluble phosphorus and make it available to plant roots for especie para la solubilización de fósforo, el resultado mostró que menos del $50 \%$ de las cepas pueden solubilizar fósforo insoluble, el mismo resultado fue reportado por Mohammadi (2012), quien observó una eficacia menor al 50 $\%$ en la solubilización del fósforo insoluble. El análisis de varianza fue altamente significativo para el 
Rev. Fac. Agron. (LUZ). 2021, 38(4): 951-969. Octubre-Diciembre.

García et al.

ISSN 2477-9407

absorption (Awais et al., 2017), they are predominately concentrated in rhizosphere (Chen et al., 2006). tiempo de solubilización del fósforo (24, 48 y 72 h) y los tratamientos (bacterianos) (cuadro 1).

Table 2. Tukey's means comparison $(P=0.05)$ of phosphorus solubilization bacterial isolated from sugarcane rhizosphere.

Cuadro 2. Comparación de medias de Tukey $(P=0,05)$ de bacterias solubilizadoras de fósforo aisladas de la rizosfera de la caña de azúcar.

\begin{tabular}{ccc}
\hline Number & Treatments & Average \\
\hline T12 & Pseudomonas mediterranea & $21.6^{\mathrm{a}} \pm 1.38$ \\
T1 & Bacillus aryabhattai & $14.4^{\mathrm{b}} \pm 1.38$ \\
T2 & Bacillus megaterium & $14.1^{\mathrm{b}} \pm 1.38$ \\
T11 & Pseudomonas koreensis & $13.7^{\mathrm{b}} \pm 1.38$ \\
T14 & Pseudomonas sp. & $11.5^{\mathrm{c}} \pm 1.38$ \\
T13 & Pseudomonas putida & $11.1^{\mathrm{c}} \pm 1.38$ \\
T3 & Bacillus mycoides & $09.6^{\mathrm{d}} \pm 1.38$ \\
T7 & Ensifer adhaerens & $09.5^{\mathrm{d}} \pm 1.38$ \\
T4 & Bacillus pumilus & $09.0^{\mathrm{e}} \pm 1.38$ \\
T10 & Paenibacillus illinoisensis & $08.8^{\mathrm{e}} \pm 1.38$ \\
T6 & Bacillus thuringensis & $08.3^{\mathrm{f}} \pm 1.38$ \\
T5 & Bacillus safensis & $07.3^{\mathrm{f}} \pm 1.38$ \\
T9 & Paenibacillus illinoisensis & $07.3^{\mathrm{f}} \pm 1.38$ \\
T8 & Paenibacillus barcinonensis & $05.0^{\mathrm{f}} \pm 1.38$ \\
T15 & Streptomyces venezuelae & $03.8^{\mathrm{h}} \pm 1.38$ \\
T16 & Terribacillus saccharophilus & $03.3^{\mathrm{h}} \pm 1.38$ \\
\hline
\end{tabular}

a, b, c, d, e, f, g, hMeans with different letters are significantly different $(P=0.05)$.

a, b, c, d, e, f, g, hMedias con letras diferentes son significativamente diferentes $(P=0,05)$.

In these analyses, $42 \%$ of bacteria in sugarcane rhizosphere have ability to solubilize insoluble phosphorus, mainly Bacillus and Pseudomonas genera, like that observed by Mohammadi (2012), PSB bacteria belong to genera Bacillus, Pseudomonas, Rhizobium and
La prueba de Tukey $(\mathrm{P}=$ 0,05) mostró que Pseudomonas mediterranea $(21,6 \mathrm{~mm})$ tuvo la mayor solubilización de fósforo, seguida por Bacillus aryabhattai (14,4 $\mathrm{mm})$ (cuadro 2).

Esto es importante ya que el fósforo es uno de los macroelementos 


\section{Rev. Fac. Agron. (LUZ). 2021, 38(4): 951-969. Octubre-Diciembre.}

Enterobacter, these bacteria can be used as biofertilizers (de Santi Ferrara et al., 2012). Biofertilizers represent a sustainable solution to improve plant growth, nutrition, root growth, productivity, and response to stress factors (Sharma et al., 2013; Anand et al., 2016).

HPLC analysis. HPLC analysis results showed that Bacillus aryabhattai $(6.0 \mathrm{ppm}), \quad$ Bacillus safensis (50.9 ppm), Bacillus pumilus (5.8 ppm) and Ensifer adhaerens (5.6 ppm) had highest production of 3 -indoleacetic acid (IAA). These results agree with those reported by Lee et al. (2012), who reported that Bacillus aryabhattai strain LS15 generated highest production IAA and Souza (2016) reported that Ensifer adhaerens have ability to fix atmospheric nitrogen and IAA production.

Different Rhizobacteria genera have ability to produce and secrete chemical compounds regulate and promote plant growth (Ashraf et al., 2011). IAA-producing bacteria have longer survival and colonize plant roots better than other bacteria (Etesami et al., 2015), weakening the plant defense mechanisms. In these results, Bacillus genus had a great capacity to produce IAA which may be due to ability to release growthpromoting substances and have a better capacity for adaptation and colonization of sugarcane rhizosphere in soils of Tamaulipas state, such as was observed by de Santi Ferrara et al. (2012). Production of phytohormones, such as auxins or gibberellins, is a direct mechanism that is used by esenciales necesarios para el crecimiento y desarrollo de las plantas, sin embargo, solo hay una pequeña fracción de fósforo en la solución del suelo (1 ppm o 0,1\%) (Awais et al., 2017). Las bacterias solubilizadoras de fosfato (PSB) tienen la capacidad de solubilizar el fósforo insoluble y ponerlo a disposición de las raíces de las plantas para su absorción (Awais et al., 2017), se concentran predominantemente en la rizósfera (Chen et al., 2006).

En estos análisis, el $42 \%$ de las bacterias en la rizósfera de la caña de azúcar tienen capacidad para solubilizar fósforo insoluble, principalmente los géneros Bacillus y Pseudomonas, como el observado por Mohammadi (2012), las bacterias PSB pertenecen a los géneros Bacillus, Pseudomonas, Rhizobium y Enterobacter, estas bacterias pueden ser utilizados como biofertilizantes (de Santi Ferrara et al., 2012). Los biofertilizantes representan una solución sostenible para mejorar el crecimiento de las plantas, la nutrición, el crecimiento de las raíces, la productividad y la respuesta a los factores de estrés (Sharma et al., 2013; Anand et al., 2016).

Análisis por HPLC. Los resultados del análisis de HPLC mostraron que Bacillus aryabhattai (6,0 ppm), Bacillus safensis (50,9 ppm), Bacillus pumilus (5,8 ppm) y Ensifer adhaerens (5,6 ppm) tuvieron la mayor producción de ácido 3-indolacético (IAA). Estos resultados concuerdan con los reportados por Lee et al. (2012), quienes informaron que la cepa LS15 de Bacillus aryabhattai 
Rev. Fac. Agron. (LUZ). 2021, 38(4): 951-969. Octubre-Diciembre.

García et al.

ISSN 2477-9407

PGR microorganisms. IAA is one of the most physiologically active auxins which controls many physiological processes including stimulation of cell division, cell elongation, cell differentiation, light and gravitational responses, and regulation of leaf fall and fruit ripening (Massena and dos Santos, 2015).

The bacterial evaluation under greenhouse conditions, the chlorophyll nitrogen amount in leaves and shoots number per plant showed highly significant differences in ANOVA analysis (table 3). generó la mayor producción de IAA y Souza (2016) informaron que Ensifer adhaerens tiene la capacidad de fijar nitrógeno atmosférico y la producción de IAA.

Los diferentes géneros de Rhizobacteria tienen la capacidad de producir y secretar compuestos químicos que regulan y promueven el crecimiento de las plantas (Ashraf et al., 2011). Las bacterias productoras de IAA tienen una supervivencia más prolongada y colonizan las raíces de las plantas mejor que otras bacterias (Etesami et al., 2015), lo que debilita

Table 3. Analysis of variance for amount of nitrogen, chlorophyll and number of shoots traits in sugarcane cultivar CP 722086 inoculated with bacteria isolated from rhizosphere of sugarcane in Tamaulipas state, Mexico.

Cuadro 3. Análisis de varianza para las características cantidad de nitrógeno, clorofila y número de brotes en el cultivar de caña de azúcar CP 72-2086 inoculado con bacterias aisladas de la rizósfera de la caña de azúcar en el estado de Tamaulipas, México.

\begin{tabular}{cccc}
\hline $\begin{array}{c}\text { Variation } \\
\text { source }\end{array}$ & $\begin{array}{c}\text { Chlorophyll } \\
\text { content }\end{array}$ & $\begin{array}{c}\text { Nitrogen } \\
\text { content }\end{array}$ & $\begin{array}{c}\text { Shoot } \\
\text { number }\end{array}$ \\
\hline Treatments & $2975.64^{* *}$ & $4045.72^{* *}$ & $0.0022^{* *}$ \\
Repetitions & $67.70^{\mathrm{ns}}$ & $0.588^{\mathrm{ns}}$ & $0.9052^{\mathrm{ns}}$ \\
Error & 35.00 & 15.46 & 0.0194 \\
CV $(\%)$ & 11.00 & 10.00 & 10.00 \\
\hline
\end{tabular}

$\mathrm{CV}=$ Coefficient of variation; $\mathrm{ns}=$ no significance $(\mathrm{P}=0.01)$.

$\mathrm{CV}=$ coeficiente de variación $; \mathrm{ns}=\sin$ importancia $(\mathrm{P}=0,01)$.

Tukey's test $(\mathrm{P}=0.05)$ showed that Ensifer adhaerens and Bacillus megaterium species presented highest chlorophyll and nitrogen averages in cultivar sugarcane $\mathrm{CP}$ 72-2086. Bacillus megaterium species los mecanismos de defensa de las plantas. En estos resultados, el género Bacillus tuvo una gran capacidad de producir IAA lo cual puede deberse a la capacidad de liberar sustancias promotoras del crecimiento y tener 
Rev. Fac. Agron. (LUZ). 2021, 38(4): 951-969. Octubre-Diciembre.

García et al.

ISSN 2477-9407

presented two shoots per plant that represented highest value, showing significant biostimulant behavior (table 4). Situation that is presented in the work of Cook et al. (2011), in pot growth of sugarcane plants inoculated with the species Pseudomonas luteola, P. fluorescens N50, Ochrobactrum anthropi N208 and Stenotrophomonas maltophilia 79 had the highest leaf area indices and growth rates. una mejor capacidad de adaptación y colonización de la rizósfera de la caña de azúcar en suelos del estado de Tamaulipas, como lo observó de Santi Ferrara et al. (2012). La producción de fitohormonas, como auxinas o giberelinas, es un mecanismo directo que utilizan los microorganismos PGR. IAA es una de las auxinas más fisiológicamente activas que controla muchos procesos fisiológicos, incluida

Table 4. Tukey's means comparison $(P=0.05)$ of amount of nitrogen, chlorophyll and number of shoots traits in sugarcane cultivar CP 72-2086 inoculated with bacteria isolated from rhizosphere of sugarcane in Tamaulipas state, Mexico.

Cuadro 4. Comparación de medias de Tukey $(P=0,05)$ para las características de cantidad de nitrógeno, clorofila y número de brotes en el cultivar de caña de azúcar CP 72-2086 inoculado con bacterias aisladas de la rizosfera de la caña de azúcar en el estado de Tamaulipas, México.

\begin{tabular}{ccccc}
\hline Number & Treatments & Chlorophyll content & Nitrogen content & Shoot number \\
\hline T1 & Bacillus aryabhattai & $37.8^{\mathrm{c}} \pm 1.03$ & $1.18^{\mathrm{b}} \pm 0.08$ & $2^{\mathrm{a}} \pm 0.18$ \\
T2 & Bacillus licheniformis & $45.8^{\mathrm{a}} \pm 1.03$ & $2.38^{\mathrm{a}} \pm 0.08$ & $1^{\mathrm{b}} \pm 0.18$ \\
T3 & Bacillus megaterium & $48.0^{\mathrm{a}} \pm 1.03$ & $2.53^{\mathrm{a}} \pm 0.08$ & $2^{\mathrm{a}} \pm 0.18$ \\
T4 & Bacillus pumilus & $35.2^{\mathrm{a}} \pm 1.03$ & $1.78^{\mathrm{c}} \pm 0.08$ & $2^{\mathrm{a}} \pm 0.18$ \\
T5 & Bacillus simplex & $38.6^{\mathrm{c}} \pm 1.03$ & $1.80^{\mathrm{c}} \pm 0.08$ & $2^{\mathrm{a}} \pm 0.18$ \\
T6 & Bacillus subtilis & $43.6^{\mathrm{b}} \pm 1.03$ & $2.30^{\mathrm{a}} \pm 0.08$ & $1^{\mathrm{b}} \pm 0.18$ \\
T7 & Bacillus safensis & $44.9^{\mathrm{b}} \pm 1.03$ & $2.37^{\mathrm{a}} \pm 0.08$ & $1^{\mathrm{b}} \pm 0.18$ \\
T8 & Ensifer adhaerens & $48.1^{\mathrm{a}} \pm 1.03$ & $2.50^{\mathrm{a}} \pm 0.08$ & $1^{\mathrm{b}} \pm 0.18$ \\
T9 & Pseudomonas & $30.0^{\mathrm{b}} \pm 1.03$ & $2.49^{\mathrm{a}} \pm 0.08$ & $1^{\mathrm{b}} \pm 0.18$ \\
T10 & Control & $48.0^{\mathrm{a}} \pm 1.03$ & $1.05^{\mathrm{b}} \pm 0.08$ & $4^{\mathrm{a}} \pm 0.18$ \\
\hline
\end{tabular}

a, b, c, dMeans with different letters are significantly different $(\mathrm{P}=0.05)$.

a, b, c, dMedias con letras diferentes son significativamente diferentes $(P=0,05)$.

Biological evaluations by Castellanos-González et al. (2016), showed responses to biofertilization with the combination of cachaça and la estimulación de la división celular, el alargamiento celular, la diferenciación celular, las respuestas lumínicas y gravitacionales y la regulación de la 


\section{Rev. Fac. Agron. (LUZ). 2021, 38(4): 951-969. Octubre-Diciembre.}

\section{García et al.}

phosphate rock with commercial biofertilizers EcoMic ${ }^{\circledR}$ and Azotofos ${ }^{\circledR}$, achieving increases in the number of shoots in sugarcane seedlings. Gómez et al. (2019), also with inoculation of the biofertilizer NITROFIX ${ }^{\circledR}$ provoked a stimulating response on the radical growth of the evaluated varieties of sugarcane.

\section{Conclusions}

The isolation and bacterial identification by the $16 \mathrm{~S}$ rRNA gene of the rhizosphere of the sugarcane variety $\mathrm{CP} 72-2086$ cultivated in the state of Tamaulipas, Mexico, identified in greater proportion species of the genus Bacillus.

The analysis of in vitro parameters of dissolution of phosphorus and IAA and the measured parameters of the amount of chlorophyll, nitrogen and shoots detected in the greenhouse bacterial inoculation in the sugarcane variety CP 72-2086, indicated that Bacillus megaterium and Ensifer adhaerens had the highest performance, postulating these isolates to future evaluations in sugarcane cultivated in the state of Tamaulipas, Mexico to evaluate their effect as possible biofertilizers in the production of sugarcane.

\section{Acknowledgment}

Conacyt-FOMIX-Tamaulipas: Tamaulipas Key: 00000000019961, and Instituto Politécnico Nacional.

\section{End of English Version}

caída de las hojas y la maduración del fruto (Massena y dos Santos, 2015)

La evaluación bacteriana en condiciones de invernadero, la cantidad de nitrógeno clorofílico en hojas y el número de brotes por planta mostró diferencias altamente significativas en el análisis ANAVAR (cuadro 3).

La prueba de Tukey $(\mathrm{P}=0,05)$ mostró que las especies de Ensifer adhaerens y Bacillus megaterium presentaron los promedios más altos de clorofila y nitrógeno en el cultivar de caña de azúcar CP 72-2086. Las especies de Bacillus megaterium presentaron dos brotes por planta que representaron el mayor valor, mostrando un comportamiento bioestimulante significativo (cuadro 4). Situación que se presenta en el trabajo de Cook et al. (2011), en macetas de plantas de caña de azúcar inoculadas con las especies Pseudomonas luteola, P. fluorescens N50, Ochrobactrum anthropi N208 y Stenotrophomonas maltophilia 79 tuvieron los índices de área foliar y tasas de crecimiento más altos.

Evaluaciones biológicas de Castellanos-González et al. (2016), mostraron respuestas a la biofertilización con la combinación de cachaça y roca fosfórica con biofertilizantes comerciales EcoMic ${ }^{\circledR}$ y Azotofos ${ }^{\circledR}$, logrando incrementos en el número de brotes en plántulas de caña de azúcar. Gómez et al. (2019), también con la inoculación del biofertilizante NITROFIX ${ }^{\circledR}$ provocó una respuesta estimulante sobre el crecimiento 


\section{Rev. Fac. Agron. (LUZ). 2021, 38(4): 951-969. Octubre-Diciembre.}

radical de las variedades evaluadas de caña de azúcar.

\section{Conclusiones}

El aislamiento e identificación bacteriana por el gen $16 \mathrm{~S}$ rRNA de la rizósfera de la variedad de caña de azúcar CP 72-2086 cultivada en el estado de Tamaulipas, México, identificó en mayor proporción especies del género Bacillus.

El análisis de los parámetros in vitro de disolución de fósforo e IAA y los parámetros medidos de la cantidad de clorofila, nitrógeno y brotes detectados en la inoculación bacteriana en invernadero en la variedad de caña de azúcar CP 72-2086, indicó que Bacillus megaterium y Ensifer adhaerens presentaron los mayores niveles de desempeño, postulando estos aislados para futuras evaluaciones en caña de azúcar cultivada en el estado de Tamaulipas, México para evaluar su efecto como posibles biofertilizantes en la producción de caña de azúcar.

\section{Agradecimiento}

Conacyt-FOMIX-Tamaulipas: Código Tamaulipas: 00000000019961 , e Instituto Politécnico Nacional.

\section{Literature cited}

Anand, K., B. Kumari, and M. M. Anwar. 2016. Phosphate solubilizing microbes, an effective and alternative approach as biofertilizers. Int. J. Pharm. Pharm. Sci. 82, 37-40. https:// cutt.ly/rnajSSI

Arora, P. K. and H. Bae. 2014. Identification of new metabolites of bacterial transformation of indole by gas chromatography-mass spectrometry and high performance liquid chromatography. Int. J. Anal. Chem. 2014, Article ID 239641, 5 pages, 2014. https://doi.org/10.1155/2014/239641

Ashraf, M., M. Rasool, and M. Mirza. 2011. Nitrogen fixation and indole acetic acid production potential of bacteria isolated from rhizosphere of sugarcane Saccharum officinarum L. Adv. Biol. Res. 56: 348-355. https:// cutt.ly/4najF9K

Awais, M., M. Tariq, A. Ali, Q. Ali, A. Khan, B. Tabassum, I. Nasir, and T. Husnain. 2017. Isolation, characterization, and inter-relationship of phosphate solubilizing bacteria from the rhizosphere of sugarcane and rice. Biocatal. Agric. Biotechnol. 11: 312-321. https://doi.org/10.1016/j. bcab.2017.07.018

Berkhoff, H. A. and A. C. Vinal. 1986. Congo red medium to distinguish between invasive and non-invasive Escherichia coli pathogenic for poultry. Avian Dis. 301: 117-121. https://cutt.ly/7najJGA

Bhattacharyya, P. N. and D. K. Jha, 2012. Plant growth-promoting rhizobacteria PGPR, emergence in agriculture. World J Microb Biot. 28: 1327-1350. https://doi.org/10.1007/s11274-0110979-9

Castellanos-González, L., M. AbreusJiménez, C. N. Silva-Campos, R. Rivera-Espinosa, I. Fuentes-Romero, E. Parets-Selva, R. de Mello-Prado, and M. Romero. 2016. Efecto de la adición de cachaza, roca fosfórica y biofertilizantes en el suelo sobre el contenido de fósforo y el desarrollo de plántulas de caña de azúcar. Cult. Trop. 374: 145-151. http://dx.doi. org/10.13140/RG.2.2.17308.08324

Castro-Nava, S., J. A. López-Santillán y F. Briones-Encinia. 2010. Retos y perspectivas de la caña de azúcar en Tamaulipas. CienciaUAT. 44: 38-43. https://cutt.ly/JnajZgr

Chen, Y. P., P. D. Rekha, A. B. Arun, F. T. Shen, W. A. Lai and C. C. Young. 2006. Phosphate solubilizing bacteria from subtropical soil and their tricalcium phosphate solubilizing abilities. Appl. Soil. Ecol. 341, 33-41. https://doi. org/10.1016/j.apsoil.2005.12.002 


\section{Rev. Fac. Agron. (LUZ). 2021, 38(4): 951-969. Octubre-Diciembre.}

García et al.

Cordero, J., J. R. de Freitas, and J. J. Germida. 2020. Bacterial microbiome associated with the rhizosphere and root interior of crops in Saskatchewan, Canada. Can. J. Microbiol. 661: 71-85. https:// doi.org/10.1139/cjm-2019-0330

Criollo, P. J., M. Obando, L. Sánchez, y R. Bonilla. 2012. Efecto de bacterias promotoras de crecimiento vegetal PGPR asociadas a Pennisetum clandestinum en el altiplano cundiboyacense. Corpoica Cienc. y Tecnol. Agropecu. 13(2): 189195. https://doi.org/10.21930/rcta. vol13_num2_art:254

de Santi Ferrara, F. I., Z. Machado, H. H. Soto, E. I. Segal and H. Ramos. 2012. Endophytic and rhizospheric Enterobacteria isolated from sugarcane have different potentials for producing plant growth-promoting substances. Plant Soil. 353: 409-417. https://doi.org/10.1007/s11104-0111042-1

Dhanraj, B. N. 2013. Bacterial diversity in sugarcane Saccharum officinarum L. rhizosphere of saline soil. Int. Res. J. Biol. Sci. 22: 60-64. https://cutt. ly/5nacKSS

Di Rienzo, J. A., F. Casanoves, M. G. Balzarini, L. González, M. Tablada y C. W. Robledo. 2019. InfoStat versión 2019. Centro de Transferencia InfoStat, FCA, Universidad Nacional de Córdoba, Argentina. https://cutt.ly/ InajNsM

Etesami, H., H. A. Alikhani and H. M. Hosseini. 2015. Indole-3-acetic acid IAA production trait, a useful screening to select endophytic and rhizosphere competent bacteria for rice growth promoting agents. MethodsX. 2: 72-78. https://doi.org/10.1016/j. mex.2015.02.008

Felsenstein, J. 1985. Confidence limits on phylogenies, An approach using the bootstrap. Evolution. 394: 783-791. https://doi.org/10.2307/2408678

Galperin, M. Y. 2013. Genome diversity of spore-forming firmicutes. Microbiol. Spectr.12: TBS-0015-2012. https://doi. org/10.1128/microbiolspectrum.TBS0015-2012
Gómez, E., Y.Guevara, A. N. San Juan, T. Lemes, M. Pérez and Y. Cutiño. 2019. Efecto del inoculante NITROFIX ${ }^{\circledR}$ sobre el desarrollo radical en tres variedades de caña de azúcar. Cent. Agríc. 464: 61-64. https://cutt.ly/ Onakt1s

Hernández-Mendoza, J. L., J. D. QuirozVelásquez, J. G. García-Olivares, C. Lizarazo-Ortega, M. C. MartínezRodríguez y M. A. Ibarra-Rodríguez. 2018. Análisis económico del uso de biofertilizantes comerciales en el cultivo de sorgo. Rev. Fac. Agron (LUZ). 35(4): 496-513. https://cutt.ly/ RnakbeF

Heryania, H. and M. Dharma-Putrab. 2017. Kinetic study and modeling of biosurfactant production using Bacillus sp. Electron. J. Biotechnol. 27: 49-54. https://doi.org/10.1016/j. ejbt.2017.03.005

Kimura, M. A. 1980. Simple method for estimating evolutionary rate of base substitutions through comparative studies of nucleotide sequences. J. Mol. Evol. 16: 111-120. http://dx.doi. org/10.1016/j.dib.2017.05.037

Lee, S., J. O. Ka, and H. G. Song. 2012. Growth promotion of Xanthium italicum by application of rhizobacterial isolates of Bacillus aryabhattai in microcosm soil. J. Microbiol. 501: 45-49. https://doi. org/10.1007/s12275-012-1415-z

Lim, S. M., M. Y. Yoon, G. J. Choi, Y. H. Choi, K. S. Jang, T. S. Shin, H. W. Park, N. H. Yu, Y. H. Kim and J. C. Kim. 2017. Diffusible and volatile antifungal compounds produced by an antagonistic Bacillus velezensis G341 against various phytopathogenic fungi. Plant Pathol. J. 335: 488-498. https://doi. org/10.5423/PPJ.OA.04.2017.0073

Männistö, M. K., E. Kurhela, M. Tirola and M. M. Häggblom. 2013. Acidobacteria dominate the active bacterial communities of Arctic tundra with widely divergent winter-time snow accumulation and soil temperatures. FEMS Microbiol. Ecol. 841: 4759. https://doi.org/10.1111/15746941.12035 
Rev. Fac. Agron. (LUZ). 2021, 38(4): 951-969. Octubre-Diciembre.

García et al.

ISSN 2477-9407

Massena, V. and K. dos Santos. 2015. Nitrogen fixing bacteria in the family Acetobacteraceae and their role in agricultura. J. Basic Microbiol. 558: 931-949. https://doi.org/10.1002/ jobm.201400898

Mohammadi, K. 2012. Phosphorus solubilizing bacteria, occurrence, mechanisms, and their role in crop production. Resources and Environment, 2: 80-85.

Momose, A., N. Ohtake, K. Sueyoshi, T. Sato, Y. Nakanishi, S. Akao and T. Ohyama. 2009. Nitrogen fixation and translocation in young sugarcane Saccharum officinarum L. plants associated with endophytic nitrogenfixing bacteria. Microbes Environ. 243: 224-230. https://doi.org/10.1264/jsme2. me09105

Morgan, J. A. W., G. D. Bending, and P. J. White. 2005. Biological costs and benefits to plant-microbe interactions in the rhizosphere. J. Exp. Bot. 56(417): 1729-1739. https://doi.org/10.1093/jxb/ eri205

Mullis, K. B. and F. A. Faloona. 1987. Specific synthesis of DNA in vitro via a polymerase-catalyzed chain reaction. Methods Enzymol. 155: 335-350. https://doi.org/10.1016/007668798755023-6

Naveed, M., S. Mubeen, S. U. khan, I. Ahmed, N. Khalid, H. A. Rasul-Suleria, A. Bano, and A. S. Mumtaz. 2014. Identification and characterization of rhizospheric microbial diversity by $16 \mathrm{~S}$ ribosomal RNA gene sequencing. Braz. J. Microbiol. 453: 985-993. https://doi. org/10.1590/s1517-83822014000300031

Nopparat,C.,M.Jatupornpipat, andA.Rittiboon. 2009. Optimization of the phosphatesolubilizing fungus, Aspergillus japonicus SA22P3406, in solid-state cultivation by response surface methodology. Witthayasan Kasetsat. 435: 172-181. https://cutt.ly/enacb2n

Pisa, G., G. Magnani, H. Weber, E. M. Souza, H. Faoro, R. A. Monteiro, E. Daros, V. Baura, J. P. Bespalhok, F. O. Pedrosa and L. M. Cruz. 2011. Diversity of $16 \mathrm{~S}$ rRNA genes from bacteria of sugarcane rhizosphere soil. Braz. J. Med. Biol. Res. 4412: 1215-1221. https://doi. org/10.1590/s0100-879x2011007500148
Quecine, M. C., W. L. Araújo, P. B. Rossetto, A. Ferreira, S. Tsui, P. T. Lacava, M. Mondin, J. L. Azevedo, and A. A. Pizzirani-Kleinera. 2012. Sugarcane growth promotion by the endophytic bacterium Pantoea agglomerans. Appl. Environ. Microbiol. 7821: 7511-7518. https://doi.org/10.1128/AEM.00836-12

Saharan, B. S. and V. Nehra. 2011. Plant growth promoting rhizobacteria, A critical review. LSMR. 1-30. https:// cutt.ly/HnaxyPZ

Serna-Cock, L., C. Arias-García and L. J. Valencia Hernández. 2011. Efecto de la biofertilización sobre el crecimiento en maceta de plantas de caña de azúcar Saccharum officinarum L. Biotecnol. sector agropecuario agroind. 92: 85-95. https://cutt.ly/gnavuV8

Sharma S. B., Sayyed, R. Z., Trivedi, M. H. and Gobi, T. A. 2013. Phosphate solubilizing microbes, sustainable approach for managing phosphorus deficiency in agricultural soils. SpringerPlus. 2: 587. https://cutt.ly/0nalT8X

Solanki, M. K., Z. Wang, F. Y. Wang, Ch. N. Li, T. J. Lan, R. K. Singh, P. Singh, L. T. Yang and Y. R. Li, 2017. Intercropping in sugarcane cultivation influenced the soil properties and enhanced the diversity of vital diazotrophic bacteria. Sugar Tech. 19: 136-147. https://doi. org/10.1007/s12355-016-0445-y

Souza, A. K. 2016. Bactérias promotoras de crescimento de plantas associadas à diferentes doses de fertilização nitrogenada na cultura do trigo. Dissertação Mestrado em Agronomia - Universidade Estadual do Oeste do Paraná, Marechal Cândido Rondon. 59 p. https://cutt.ly/VnalOhk

Swanson, K. M., R. L. Petran, and J. H. Hanlin. 2001. Culture methods for enumeration of microorganisms". In: Compendium of methods for the microbiological examination of foods. 4th ed. Downs, F. P. and Ito, K. Eds. APHA. Washington. 53-67.

Torriente, D. 2010. Aplicación de bacterias promotoras de crecimiento vegetal en el cultivo de la caña de azúcar. Perspectivas de su uso en Cuba. Cult. Trop. 311: 19-26. https://cutt.ly/ ynalAED 